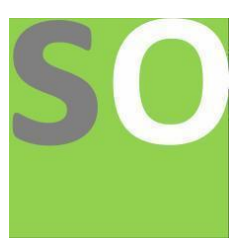

Article title: Evaluation on Study Skills and Academic Stress on University Engineering Students' Academic Achievement Authors: Mustefa Jibril[1]

Affiliations: Dire Dawa University, Dire Dawa, Ethiopia[1]

Orcid ids: 0000-0002-3165-2410[1]

Contact e-mail: mustefazinet1981@gmail.com

License information: This work has been published open access under Creative Commons Attribution License $\mathrm{http}: / / c r e a t i v e c o m m o n s . o r g / l i c e n s e s / b y / 4.0 /$, which permits unrestricted use, distribution, and reproduction in any medium, provided the original work is properly cited. Conditions, terms of use and publishing policy can be found at https://www.scienceopen.com/.

Preprint statement: This article is a preprint and has not been peer-reviewed, under consideration and submitted to ScienceOpen Preprints for open peer review.

DOI: 10.14293/S2199-1006.1.SOR-.PPCUVI9.v1

Preprint first posted online: 27 June 2021

Keywords: Study Skills, Academic-related stress, Academic-performance, Engineering Students. 


\title{
Evaluation on Study Skills and Academic Stress on University Engineering Students' Academic Achievement
}

\author{
Mustefa JIBRIL \\ School of Electrical \& Computer Engineering, Dire Dawa Institute of Technology, Dire Dawa, Ethiopia \\ mustefa.jibril@ddu.edu.et
}

\begin{abstract}
This study aimed to examine the influence it is to study skills and academic-related stress in the academic performance of the students of the university. A descriptive research project was used. The study was carried out among students of engineering at the University of Dire Dawa. The study involved 400 students of the engineering bachelor's degrees, one hundred and, from the second to the fifth year, which has been evaluated for the academic stress and to study skills. A random sample is used to select objects for the study of the system. Three tools were used: Tool I: Socio-demographic Profile Sheet, Tool II: Study Skills Assessment Questionnaire, Tool III: Perceived Stress Scale. The results of this study showed that the students performed well in all the subjects, except for the time-management method and writing skills. More than two-thirds of the surveyed students have a low level of stress. Academic stress is higher in senior and female students. There was a negative correlation between the students ' stress and their study skills. Statistically significant relationships were found between academic performance, study skills, and the stress level of the students surveyed.
\end{abstract}

Keywords: Study Skills, Academic-related stress, Academic-performance, Engineering Students.

\section{Introduction}

Academic achievement or academic performance depends on how well the student, teacher or institution achieves their short- or long-term educational goals. The completion of educational benches such as high school diplomas and bachelor's degrees represents academic success [1][3]. Academic achievement refers to academic results that show how much a learner has achieved in his or her learning goals. Succeeding in studies can mean completing academic qualifications such as a bachelor's degree. Academic achievement is often measured by success or failure [4].

Academic achievement is the way a student or institution achieves short- or long-term educational goals [5]. Success can be measured by the grade point average, and in institutions, success can be measured at graduation rates. In a general sense, academic achievement is the current level of student learning. Specifically, for ESSA's accountability, academic achievement refers to the percentage of students in a school whose current education meets or exceeds their grade levels [6]-[7].

Academic achievement is important because it is closely linked to the good results we value. Adult graduates with higher education are more likely to be employed, have a stable job, have more employment opportunities than those who are less educated and earn higher wages, are more likely to have health insurance, are more dependent on social services, less likely to engage 
in crime, are more active as citizens and volunteers who help and are healthier and happier. Academic achievement is important because working people will need higher levels of education to deal with future technical careers. Now a day you need post-secondary education to get a job [7]. Graduates have high self-esteem, low levels of depression and anxiety, social tension, and a lower risk of alcohol abuse and drug abuse. Good self-confidence and self-confidence are key elements in a commitment to academic success [5][8].

People, better organized, better prepared and have an organizational plan and their organizers do better in school and will continue to be so in their work. Organization, time management, prioritization, focus and motivation find success in education. When it comes to organizational skills that can be as important as reading, writing and math to build a perfect, independent person [9]. Academic achievement is essential to the successful development of young people in society. Students who excel in school are better able to make the transition to adulthood and to achieve success in the workplace and in the economy [3].

\section{Aim of the study:}

To assess the effect of study skills and academic stress on the academic achievement of Engineering students of Dire Dawa University.

\section{Research questions:}

1. What is the effect of academic stress on engineering students' academic achievement?

2. What is the effect of study skills on engineering students' achievement?

3. What is the relation between study skills, academic stress, and engineering students' achievement?

\section{Materials and method:}

\section{Research design:}

A descriptive research design was used in this study.

\section{Setting:}

This study was conducted at Dire Dawa University.

\section{Subjects:}

The study involved 400 students of the second through the fifth-year engineering students who have been assessed in the study skills and academic stress, and to learn the skills. A random sample is to be used for the selection of the systems under study. The sample size was calculated using EPI-Info, version 6, which is taken to be 50\% of the frequency of students ' study, stress, and academic development. The value of 5\% is chosen, the precision at the $95 \%$ level of confidence. The calculated size of the random sample of 385 engineering students, who have grown up to 400 to protect against a lack of response.

\section{Result and Discussion}

Table (1) shows that the average age of the students was 20.58 \pm 1.33 ). The majority of the students were female (86.5\%). More than half of them live in rural areas, and their homes $(57.5 \%$ and $54 \%$, respectively).

Table (1): Frequency distribution of the surveyed students on their characteristics $(n=$ 400).

\begin{tabular}{|l|l|l|}
\hline Personal characteristic & No. $\mathbf{( 4 0 0 )}$ & \% \\
\hline Age: & & \\
\hline $18-23$ years & 197 & 49.3 \\
\hline
\end{tabular}




\begin{tabular}{|l|l|l|}
\hline$>23$ years & 203 & 50.8 \\
\hline Mean \pm SD (Range) & $\mathbf{2 0 . 5 8} \pm \mathbf{1 . 3 3}(\mathbf{1 8 . 0}-\mathbf{2 4 . 0})$ \\
\hline Gender: & \multicolumn{2}{|l|}{} \\
\hline Male & 54 & \\
\hline Female & 346 & 13.5 \\
\hline Class year: & & $\mathbf{8 6 . 5}$ \\
\hline Second & 100 & \\
\hline Third & 100 & 25.0 \\
\hline Fourth & 100 & 25.0 \\
\hline Fifth & 100 & 25.0 \\
\hline Residence: & & 25.0 \\
\hline Rural & 230 & \\
\hline Urban & 170 & $\mathbf{5 7 . 5}$ \\
\hline Students living place & & 42.5 \\
\hline Living with Family & 216 & \\
\hline Living in University & 160 & $\mathbf{5 4 . 0}$ \\
\hline Living in private House & 24 & 40.0 \\
\hline
\end{tabular}

Table (2) shows that the students are good for all of the educational and study skills, and except for the time-management method, as well as the writing skills, is that there is $68.3 \%$, and $58.5 \%$, respectively).

Table (2): Frequency distribution of the surveyed students on their study skills $(n=400)$.

\begin{tabular}{|l|l|l|}
\hline Study skills items & No. $(\mathbf{n}=\mathbf{4 0 0})$ & $\mathbf{\%}$ \\
\hline Time Management Method: & & \\
\hline Poor $(<60 \%)$ & 273 & $\mathbf{6 8 . 3}$ \\
\hline Good $(\geq 60 \%)$ & 127 & 31.8 \\
\hline Concentration Method: & & \\
\hline Poor $(<60 \%)$ & 129 & 32.3 \\
\hline Good $(\geq 60 \%)$ & 271 & 67.8 \\
\hline Note Taking Method & & \\
\hline Poor $(<60 \%)$ & 85 & 21.3 \\
\hline Good $(\geq 60 \%)$ & 315 & 78.8 \\
\hline Test Strategies Method & & \\
\hline Poor $(<60 \%)$ & 130 & 32.5 \\
\hline Good $(\geq 60 \%)$ & 270 & 67.5 \\
\hline Processing Information Method & & \\
\hline Poor $(<60 \%)$ & 147 & 36.8 \\
\hline Good $(\geq 60 \%)$ & 253 & 63.3 \\
\hline Motivation and Attitude Scale & & \\
\hline Poor $(<60 \%)$ & 199 & 49.8 \\
\hline Good $(\geq 60 \%)$ & 201 & 50.3 \\
\hline Reading and exploring the Main Idea: & & \\
\hline Poor $(<60 \%)$ & 189 & 47.3 \\
\hline Good $(\geq 60 \%)$ & 211 & 52.8 \\
\hline Writing skill & & \\
\hline
\end{tabular}




\begin{tabular}{|l|l|l|}
\hline Poor $(<60 \%)$ & 234 & $\mathbf{5 8 . 5}$ \\
\hline Good $(\geq 60 \%)$ & 166 & 41.5 \\
\hline Total study skills: & & \\
\hline Poor $(<60 \%)$ & 166 & 41.5 \\
\hline Good $(\geq 60 \%)$ & 234 & 58.5 \\
\hline
\end{tabular}

$*<60 \%$ means Good $* * 260 \%$ means Poor

The data presented in Table (3) showed that there was no statistically significant relationship between the level of stress and the individual characteristics of the students being tested, such as age, year of study, place of residence, and the current state of the lives of the students, however, there was a statistically significant relationship with gender $(\mathrm{p}=0.009)$.

Table 3: The Relationship between the personal characteristics of the studied students, and their stress levels $(n=400)$

\begin{tabular}{|c|c|c|c|c|c|c|c|}
\hline \multirow[t]{3}{*}{ Personal characteristics } & \multicolumn{6}{|c|}{ Stress level } & \multirow[t]{3}{*}{ P-value } \\
\hline & \multicolumn{2}{|c|}{$\begin{array}{l}\text { Low } \\
(n=76)\end{array}$} & \multicolumn{2}{|c|}{$\begin{array}{l}\text { Moderate } \\
(n=266)\end{array}$} & \multicolumn{2}{|c|}{$\begin{array}{l}\text { High } \\
(n=58)\end{array}$} & \\
\hline & No. & $\%$ & No. & $\%$ & No. & $\%$ & \\
\hline \multicolumn{7}{|l|}{ Age: } & \multirow[t]{3}{*}{0.085} \\
\hline $18-23$ years & 45 & 22.8 & 121 & 61.4 & 31 & 15.7 & \\
\hline$>23$ years & 31 & 15.3 & 145 & 71.4 & 27 & 13.3 & \\
\hline \multicolumn{7}{|l|}{ Gender: } & \multirow[t]{3}{*}{$0.009 *$} \\
\hline Male & 16 & 29.6 & 26 & 48.1 & 12 & 22.2 & \\
\hline Female & 60 & 17.3 & 240 & 69.4 & 46 & 13.3 & \\
\hline \multicolumn{7}{|l|}{ Class year: } & \multirow[t]{5}{*}{0.175} \\
\hline Second & 14 & 14.0 & 66 & 66.0 & 20 & 20.0 & \\
\hline Third & 26 & 26.0 & 65 & 65.0 & 9 & 9.0 & \\
\hline Fourth & 16 & 16.0 & 68 & 68.0 & 16 & 16.0 & \\
\hline Fifth & 20 & 20.0 & 67 & 67.0 & 13 & 13.0 & \\
\hline \multicolumn{7}{|l|}{ Residence: } & \multirow[t]{3}{*}{0.226} \\
\hline Rural & 39 & 17.0 & 161 & 70.0 & 30 & 13.0 & \\
\hline Urban & 37 & 21.8 & 105 & 61.8 & 28 & 16.5 & \\
\hline \multicolumn{7}{|l|}{ Students living place } & \multirow[t]{4}{*}{0.703} \\
\hline Living with Family & 44 & 20.4 & 143 & 66.2 & 29 & 13.4 & \\
\hline Living in University & 28 & 17.5 & 105 & 65.6 & 27 & 16.9 & \\
\hline Living in private House & 4 & 16.7 & 18 & 75.0 & 2 & 8.3 & \\
\hline
\end{tabular}

*Significant at $\mathbf{p}<0.05$

Table (4) showed that (66.5\%) of the sample are older than 20 years $(68.5 \%)$ of the male $(72.0 \%)$ third-year students, and (59.7\%) of the students who lived in the family home, had a great ability to study skill. There was a statistically significant relationship between the study skill of the students ' abilities, and personal characteristics such as age and year of study $(\mathrm{p}=0.001)$, but there was not a statistically significant relationship with gender, place of residence, and the current state of the living of a student.

Table (4): The Relationship between the personal characteristics of the survey of students and their assessment of the study skills $(n=400)$. 


\begin{tabular}{|c|c|c|c|c|c|}
\hline \multirow[t]{3}{*}{ Personal characteristics } & \multicolumn{4}{|c|}{ Study skills } & \multirow[t]{3}{*}{ P-value } \\
\hline & \multicolumn{2}{|c|}{$\begin{array}{l}\text { Poor }(<60 \%) \\
(n=166)\end{array}$} & \multicolumn{2}{|c|}{$\begin{array}{l}\text { Good }(\geq 60 \%) \\
(n=234)\end{array}$} & \\
\hline & No. & $\%$ & No. & $\%$ & \\
\hline \multicolumn{5}{|l|}{ Age: } & \multirow[t]{3}{*}{ 0.001* } \\
\hline $18-23$ years & 98 & 49.7 & 99 & 50.3 & \\
\hline$>23$ years & 68 & 33.5 & 135 & 66.5 & \\
\hline \multicolumn{5}{|l|}{ Gender: } & \multirow[t]{3}{*}{0.108} \\
\hline Male & 17 & 31.5 & 37 & 68.5 & \\
\hline Female & 149 & 43.1 & 197 & 56.9 & \\
\hline \multicolumn{5}{|l|}{ Class year: } & \multirow[t]{5}{*}{ 0.001* } \\
\hline Second & 56 & 56.0 & 44 & 44.0 & \\
\hline Third & 42 & 42.0 & 58 & 58.0 & \\
\hline Fourth & 28 & 28.0 & 72 & 72.0 & \\
\hline Fifth & 40 & 40.0 & 60 & 60.0 & \\
\hline \multicolumn{5}{|l|}{ Residence: } & \multirow[t]{3}{*}{0.926} \\
\hline Rural & 95 & 41.3 & 135 & 58.7 & \\
\hline Urban & 71 & 41.8 & 99 & 58.2 & \\
\hline \multicolumn{5}{|l|}{ Students living place } & \multirow{4}{*}{0.858} \\
\hline Living with Family & 87 & 40.3 & 129 & 59.7 & \\
\hline Living in University & 69 & 43.1 & 91 & 56.9 & \\
\hline Living in private House & 10 & 41.7 & 14 & 58.3 & \\
\hline
\end{tabular}

*Significant at $\mathbf{p}<0.05$

Table (5) shows that there are statistically significant differences between the students ' stress, and some of the variables and the study skills, such as time management Method, processing of the information method, the motivation, and attitude scale, reading, and exploring main ideas, and lists, as in the other variables, no significant differences were found.

Table (5): Correlation between the students, from the stress, and the learning of skills Study Skills items

\begin{tabular}{|l|l|l|}
\cline { 2 - 3 } & R-value & P-value \\
\hline Time Management Method & -0.132 & $\mathbf{0 . 0 0 8} *$ \\
\hline Noncentration Method & -0.043 & 0.392 \\
\hline Test Strategies Method & 0.007 & 0.896 \\
\hline Processing Information Method & -0.063 & 0.206 \\
\hline Motivation and Attitude Scale & -0.118 & $\mathbf{0 . 0 1 8} *$ \\
\hline Reading and exploring the Main Idea: & -0.324 & $\mathbf{0 . 0 0 0} *$ \\
\hline Writing skill & -0.166 & $\mathbf{0 . 0 0 1} *$ \\
\hline Total Study skills & -0.247 & $\mathbf{0 . 0 0 0} *$ \\
\hline & -0.195 & $\mathbf{0 . 0 0 0} *$ \\
\hline
\end{tabular}

The following Table (6), and the data are presented in Table (6) show that there is a statistically significant correlation between the students, from the stress and the three components of their 
study skills, such as motivation and attitudes scale, and the reading and exploring main ideas, and writing skills ( $\mathrm{p}=0.000, * 0,030 * 0,000 *$ accordingly). There are, however, no statistically significant correlation was also found for the other ability training topics. In the aggregate, have a statistically significant relationship was found between the students 'stress level, as well as their study skills $(\mathrm{p}=0.017)$.

Table (6): Correlation between the subjects of the study, students ' abilities, and their stress levels $(n=400)$

\begin{tabular}{|c|c|c|c|c|}
\hline \multirow[b]{2}{*}{ Study Skills Items } & \multicolumn{3}{|l|}{ Stress level } & \multirow{2}{*}{$\begin{array}{l}P \text { - } \\
\text { value }\end{array}$} \\
\hline & $\begin{array}{l}\text { Low } \\
(n=76) \\
\text { Mean } \pm \text { SD }\end{array}$ & $\begin{array}{l}\text { Moderate } \\
(n=266) \\
\text { Mean } \pm \text { SD }\end{array}$ & $\begin{array}{l}\text { High } \\
(n=58) \\
\text { Mean } \pm \text { SD }\end{array}$ & \\
\hline Time Management Method & $\begin{array}{l}17.95 \\
5.99\end{array}$ & $17.13 \pm 4.57$ & $\begin{array}{l}16.03 \quad \pm \\
5.05\end{array}$ & 0.086 \\
\hline Concentration Method & $\begin{array}{l}21.51 \\
5.63\end{array}$ & $21.83 \pm 4.50$ & $\begin{array}{l}21.19 \\
5.09\end{array}$ & 0.622 \\
\hline Note Taking Method & $\begin{array}{l}22.50 \\
5.34\end{array}$ & $23.29 \pm 4.28$ & $\begin{array}{l}22.64 \\
5.98\end{array}$ & 0.349 \\
\hline Test Strategies Method & $\begin{array}{l}21.64 \\
5.45\end{array}$ & $21.58 \pm 4.59$ & $\begin{array}{l}20.79 \\
5.95\end{array}$ & 0.527 \\
\hline Processing Information Method & $\begin{array}{l}21.78 \\
5.17\end{array}$ & $21.24 \pm 5.20$ & $\begin{array}{l}20.10 \\
6.00\end{array}$ & 0.187 \\
\hline Motivation and Attitude Scale & $\begin{array}{l}21.76 \\
5.19\end{array}$ & $19.86 \pm 4.93$ & $\begin{array}{l}17.29 \\
5.79\end{array}$ & $0.000 *$ \\
\hline $\begin{array}{l}\text { Reading and exploring the Main } \\
\text { Idea: }\end{array}$ & $\begin{array}{l}20.87 \\
6.11\end{array}$ & $19.09 \pm 4.80$ & $\begin{array}{l}19.21 \\
5.53\end{array}$ & $0.030 *$ \\
\hline Writing skill & $\begin{array}{l}20.78 \quad \pm \\
6.05\end{array}$ & $17.74 \pm 4.64$ & $\begin{array}{l}17.26 \quad \pm \\
4.87\end{array}$ & $0.000 *$ \\
\hline Total study skills & $\begin{array}{l}168.79 \pm 33 \\
00\end{array}$ & $161.76 \pm 26.55$ & $\begin{array}{l}154.52 \pm 31 \\
54\end{array}$ & $0.017 *$ \\
\hline
\end{tabular}

*Significant at $\mathbf{p}<0.05$

Table (7): Shows that there is a statistically significant relationship between the students ' academic performance, study skill, and stress level ( $\mathrm{p}=0.0000 .001$, respectively).

Table 7: The Relationship between students ' academic achievement, study skills, and relieve stress.

\begin{tabular}{|c|c|c|c|c|c|c|c|c|c|c|c|}
\hline \multirow[t]{3}{*}{ Variables } & \multicolumn{10}{|c|}{ Academic performance } & \multirow[t]{3}{*}{ P-value } \\
\hline & \multicolumn{2}{|c|}{$\begin{array}{l}\text { Excellent } \\
(n=67)\end{array}$} & \multicolumn{2}{|c|}{$\begin{array}{l}\text { Very good } \\
(n=78)\end{array}$} & \multicolumn{2}{|c|}{$\begin{array}{l}\text { Good } \\
(n=131)\end{array}$} & \multicolumn{2}{|c|}{$\begin{array}{l}\text { Fair } \\
(n=85)\end{array}$} & \multicolumn{2}{|c|}{$\begin{array}{l}\text { Poor } \\
(n=39)\end{array}$} & \\
\hline & No. & $\%$ & No. & $\%$ & No. & $\%$ & No. & $\%$ & No. & $\%$ & \\
\hline \multicolumn{11}{|l|}{ Study skills: } & \multirow[t]{3}{*}{ 0.000* } \\
\hline Good & 57 & 85.1 & 54 & 69.2 & 76 & 58.0 & 40 & 47.1 & 7 & 17.9 & \\
\hline Poor & 10 & 14.9 & 24 & 30.8 & 55 & 42.0 & 45 & 52.9 & 32 & 82.1 & \\
\hline \multicolumn{11}{|l|}{ Stress level: } & \multirow[t]{3}{*}{$0.001 *$} \\
\hline Low & 23 & 34.3 & 18 & 23.1 & 24 & 18.3 & 10 & 11.8 & 1 & 2.6 & \\
\hline Moderate & 39 & 58.2 & 51 & 65.4 & 90 & 68.7 & 57 & 67.1 & 29 & 74.4 & \\
\hline
\end{tabular}




\section{High}

\begin{tabular}{|l|l|l}
5 & 7.5 & 9
\end{tabular}

$11.5 \quad 17$

13.0

18

21.29

23.1

\section{Discussion}

The present study examined the effects of academic stress, and the study skills on the performance of the students, as well as the impact of certain demographic variables such as gender, age, and level of education. The results of this study showed that the average age of the surveyed students (20.58 \pm 1.33 years), the majority of the students were female, and over half of them live in rural areas and their family members at home.

In terms of the learning of the students, the skills, the results showed that students can be good in all subjects, and the study skills, and except for the time-management method, and writing skills.

From the results, it was found that there is a significant difference between male and female students in the perception of stress, as female students are more likely to have more academic stress. This may be because females have experienced high levels of study, level of stress, due to a negative appraisal of the stressful event, their attention is focused on the emotional issues after a traumatic event.

The results of this study showed that three-quarters of the students surveyed, with moderate levels of the stress of living in private housing. This can be explained in terms of the students in a different environment, separated from their parents, as well as the need for the creation of a new social group, in addition to academic pressure, and the engineering course.

This study showed a statistically significant association between the students ' success and study skills. In addition, the results have a positive effect on the study skills. In this regard, there is a need for regular training in the intervention and skills to the students, in general, and for the firstyear students in particular. Thus, self-regulation in the learning process can be improved.

\section{Conclusion:}

The results of this study showed that bad students, for all of the educational and skills, and except for the time-management method, as well as writing skills. Academic stress is higher in older students than in younger ones. There was a negative correlation between the students ' stress and their management skills. There were statistically significant associations between academic achievement, study skills, and stress levels of the students surveyed.

\section{Recommendations:}

1. An operation in the teaching and the learning of skills, you can have a reliable means to deal with the students ' stress levels.

2. Learn the skills, and the learning of skills, the courses should be included in the student's curriculum, formal and can be implemented in the form of a seminar to the students, especially first-year students.

3. The teacher will have to find out the sources of stress and coping strategies used by students to help them deal with problems and situations. 


\section{Reference}

[1]. Fahd, Samar, et al. "IMPACT OF HOPE ON THE ACADEMIC ACHIEVEMENT OF UNIVERSITY STUDENTS OF BAHAWALPUR." Psychology and Education Journal 58.3 (2021): 2312-2321.

[2]. Afridi, Tahira, et al. "EMOTIONAL INTELLIGENCE AS PREDICTOR OF ACADEMIC ACHIEVEMENT AMONG UNIVERSITY STUDENTS: AN IMPLICATION FOR THE EDUCATIONAL MANAGERS." PalArch's Journal of Archaeology of Egypt/Egyptology 18.4 (2021): 5035-5049.

[3].Lonka, Kirsti, Elina Ketonen, and Jan D. Vermunt. "University students' epistemic profiles, conceptions of learning, and academic performance." Higher Education 81.4 (2021): 775-793.

[4]. Madigan, Daniel J., and Thomas Curran. "Does burnout affect academic achievement? A meta-analysis of over 100,000 students." Educational Psychology Review 33 (2021): 387-405.

[5].REHMAN, ASAD UR, et al. "Modeling Media Exposure, Appearance-Related Social Comparison, Thin-Ideal Internalization, Body Image Disturbance And Academic Achievement Of Female University Students." Journal of Contemporary Issues in Business and Government 27.3 (2021): 2569-2582.

[6]. Mahasneh, Ahmad Mohmmad, Ahmad Mohmmad Ghazo, and Omar Atallah Al-Adamat. "Academic Hardiness and Its Relationship with Academic Stress and Academic Achievement among Hashemite University Students." Journal of Al-Quds Open University for Educational \& Psychological Research \& Studies 12.35 (2021): 4.

[7]. Sak1z, Halis, et al. "A Longitudinal Analysis of Academic Achievement and Its Correlates in Higher Education." SAGE Open 11.1 (2021): 21582440211003085.

[8]. Asikainen, Henna, et al. "Learning profiles and their relation to study-related burnout and academic achievement among university students." Learning and Individual Differences 78 (2020): 101781.

[9]. Spence, Ruth, et al. "Life events, depression, and supportive relationships affect academic achievement in university students." Journal of American college health (2020): 1-5. 